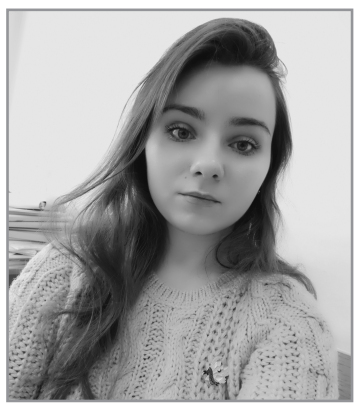

Iryna Varykasha*

Magister of Law, Lawyer of Chornomorsk port management

(Chornomorsk, Ukraine)

ORCID: https://orcid.org/0000-0003-3125-6829

*Iryna Varykasha, Magister of Law, Lawyer of Chornomorsk port management (6, Pratsi St., Chornomorsk, Ukraine).

\title{
CASE CONCERNING MARITIME DELIMITATION IN THE BLACK SEA (ROMANIA $v$. UKRAINE). INVESTIGATION OF POSITIONS
}

\section{СПРАВА ЩОДО ДЕЛІМІТАЦЇ̈ У ЧОРНОМУ МОРІ (РУМУНІЯ ПРОТИ УКРАЇНИ). ДОСЛІДЖЕННЯ ПОЗИЦЙ}

\section{ABSTRACT}

In this article, I had studied the materials about the delineation at sea, carried out, with the consent of the respective states, by the UN International Court of Justice. Such a choice is conditioned by a specific goal-to show how the International Court interpreted contractual sources of international maritime law, how it identified the applicable customary legal norms and principles, how it applied international law on the delineation at sea, to what extent the relevant factors were taken into account in specific situations of maritime delimitation, as he set forth the appropriate international legal argument. In addition, the study of the Court's materials provides opportunities to identify the legal positions of the disputing States on the problems of delineation at sea and the international legal assessment of such positions by the Court.

The key words: delimitation in the Black Sea, international law, International Court of Justice, maritime boundaries, Romania $v$. Ukraine. 


\section{Introduction}

Its interesting to get acquainted with the positions occupied by the International Court of Justice on the interpretation and application of international law on specific inter-court maritime disputes, particularly those that are of economic and political importance, such as the delineation of maritime areas, in the value dimension of the growing, both the continental shelf and the exclusive economic zone.

Precisely, in the decisions of the International Court of Justice that the content of the very concise provisions of the universal conventions on the delimitation of maritime spaces is considered most substantively.

In my work, I had studied the materials about the delineation at sea, carried out, with the consent of the respective states, by the UN International Court of Justice. Such a choice is conditioned by a specific goal to show how the International Court interpreted contractual sources of international maritime law, how it identified the applicable customary legal norms and principles, how it applied international law on the delineation at sea, to what extent the relevant factors were taken into account in specific situations of maritime delimitation, as he set forth the appropriate international legal argument. In addition, the study of the Court's materials provides opportunities to identify the legal positions of the disputing States on the problems of delineation at sea and the international legal assessment of such positions by the Court.

While studying this topic, I relied on the works of such scientists: T. V. Averochkina, E. D. Brown, O. Garina, S. V. Kivalov, S. A. Kuznetcov, C. V. Molodtsov, N. I. Riezkov, S.M. Rhee, V. V. Serafimov, A. N. Vulegjhanin and others.

The relevance of the topic the distinction between States of the continental shelf areas, the exclusive economic zone, and the territorial sea were and still remain pressing issues of science and practice of international law. Nowadays, with the geopolitical changes in the world, the emergence of new coastal states and the escalation of claims to marine natural resources, these issues are becoming urgent, and their lack of resolve creates difficulties in relations between states and even conflicts. In view of this, the need for a comprehensive scientific study of a number of contemporary problem areas of delimitation at sea, with a careful attitude towards major developments in foreign science of international law on the practical and theoretical issues of delimitation of marine spaces, has come to fruition. Among them: the features of delineation of international straits (their shores belong to two 
states, but for navigational purposes, these straits are used by many states); issues of accounting for the factors of joint exploitation of transboundary mineral resources in the interior of the continental shelf with delimitation at sea. At the same time, the study of the combination of intergovernmental treaties of the public and private economic level of regulation is in demand.

Among modern issues of international maritime law, a comprehensive study of the international legal possibilities for establishing maritime boundaries is particularly required. In practical terms, it is usually a question of the need for internationally agreed recognition as international maritime boundaries, formerly technical, administrative, or de novo delimitation of marine spaces.

\section{The history of dispute between Romania and Ukraine}

The Case concerning maritime delimitation in the Black Sea (Romania v. Ukraine) was decided unanimously on 3 February 2009 by the International Court of Justice (the Court), marking the latest judgment in a growing body of case law on maritime boundary delimitation by the Court. The case was filed by Romania against Ukraine on 16 September 2004, following twenty four rounds of unsuccessful negotiations between 1998-2004 for delimitation of the maritime area in the northwestern corner of the Black Sea, that included Serpents' Island. The Court was requested to establish a single maritime boundary between the continental shelf and exclusive economic zones (EEZ) of the Parties. The only significant geographic formation to potentially affect the drawing of the final maritime delimitation line was the presence of Serpents' Island, which according to Romania was a "rock", and according to Ukraine an "island" (Convention on the Law of the Sea). In its final award, the Court drew a maritime boundary based on "established practice", drawing a provisional equidistance line between the adjacent and opposite coasts of the Parties, making adjustments based on relevant factors to achieve an equitable result, which was then assessed on the basis of proportionality.

The Court emphasized the importance of determining the relevant coasts of Ukraine and Romania, reiterating two important principles: that the land dominates the sea and that the role of delimitation is to resolve the claims of States where their coastal projections overlap by drawing a delimitation line. After identification of the relevant coasts and maritime area, the Court found no applicable relevant factors/special circumstances requiring adjustment of the provisional maritime boundary drawn. 
Although the case presented an opportunity for the Court to shed legal light on one of the more ambiguous and in some cases contentious questions in the law of the sea, i.e., the distinction between an "island" and a "rock" under Article 121(3) of the 1982 United Nations Law of the Sea Convention (hereafter the LOSC), the Court declined the invitation and excluded Serpents' Island from its final award on other grounds (Baibekova, 2012, p. 71).

The Black Sea is a semi-enclosed sea within the meaning of LOSC Article 122. Connected to the Mediterranean Sea by the narrow Turkish Straits, it has a total surface area of $432,000 \mathrm{~km}^{2}$ (including the Azov Sea). The geography of the Black Sea is uncomplicated, with no complex island features or contested areas of sovereignty. Maritime boundary delimitation in the Black Sea, with the exception of the recent case between Ukraine and Romania, had been concluded by a series of bilateral agreements between the Black Sea coastal States, leaving no area of the Black Sea as high seas.

The history of the current dispute dates back to 1947, following World War II, and originally involved the former USSR and Romania. However, following the historic dissolution of the former USSR in 1991, Ukraine acquired a long stretch of coastal area along the north-western portion of the Black Sea, from the mouth of the Danube all the way to the Crimea Peninsula, that also included Serpents' Island. What should have otherwise presented a fairly straight-forward case for the drawing of maritime boundaries between these two States became complicated by the presence of Serpents' Island, described by Romania as a "rock" within the meaning of LOSC Article 121(3), and by Ukraine as an "island", capable of generating its own maritime zones and baselines. Serpents' Island, while of military importance in the past, currently derives its importance from potential reserves of off shore oil and gas. Serpents' Island occupies an area of no more than $0.17 \mathrm{~km}^{2}$ with a circumference of 1,973 meters; measuring 662 meters long by 440 meters wide, it is situated approximately 20 nautical miles (nm) from the Danube Delta. Th e photographs of Serpents' Island, as introduced by both Parties, showed a relatively flat maritime feature with rocky shores and little vegetation. The only structures on it were the lighthouse erected by the Ottomans and later destroyed by the Germans during World War II, and a police border station established by Ukraine.

The legal foundation of the case, apart from the relevant provisions of the LOSC, included a series of agreements concluded by Romania and the USSR between 1947 and 1997, which devolved upon Ukraine by operation 
of state succession. A further set of agreements was concluded directly by Romania and Ukraine between 1997 and 2003. Following the 1947 Paris Peace Treaty, a Soviet-Romanian Border Commission had been established to fix the State border between Romania and the USSR. The land border and part of the maritime boundary demarcation were formalized in the General Procès-Verbal of the Description of the State Border Line between the People's Republic of Romania and the Union of the Soviet Socialist Republics concluded in 1949 (1949 General Procès-Verbal). This also established a 12-nm arc around Serpents' Island, the legal effect of which was one of the key points of contention between the Parties (Dmytrychenko, 2006, p. 375). Supplementary to the 1949 General Procès-Verbal the parties also concluded individual Procès-Verbaux for discrete boundary markers. The 1949 General Procès-Verbal was followed by the Treaty between Romania and the USSR on the Regime of the Romanian-Soviet Border of 25 November 1949 (1949 Border Regime Treaty), the Treaty on the regime of the Romanian-Soviet State Border of 27 February 1961 (1961 Border Regime Treaty), and the 1963 and 1974 Procès-Verbaux. Between 1967 and 1987, Romania and the USSR were unable to reach agreement on the delimitation of the continental shelf and the EEZ despite engaging in ten rounds of negotiations. A further round of negotiations was not initiated until 1997, by which time the USSR had dissolved and Ukraine had become an independent State (Baibekova, 2012, p. 72). In 1997, Ukraine and Romania concluded the Treaty on the Relations of Good Neighborliness and Co-operation between Romania and Ukraine, signed at Constanta on 2 June 1997 (1997 Treaty). This was accompanied by the Agreement Additional to the Treaty on Relations, concluded by an exchange of letters by the Ministers of Foreign Aff airs of the two States, also dated 2 June 1997 (Additional Agreement). Finally, they concluded the Treaty between Romania and Ukraine on the Romanian-Ukrainian State Border Regime, Collaboration and Mutual Assistance on Border Matters, 2003. Both Romania and Ukraine are parties to the LOSC, which became applicable to both Parties in 1999.

\section{The positions of opponent countries( Romania v Ukraine) \\ The Romania position (base points)}

In its application and written pleadings Romania asked the Court to draw a single maritime boundary between Romania and Ukraine delimiting the continental shelf and EEZ of the Parties. The jurisdiction of the Court was 
based on Article 4(h) of the 1997 Additional Agreement.12 According to Romania the relevant provisions of the LOSC and the series of agreements dated between 1947 and 2003 constituted the applicable law for the Court to apply in the case.

More importantly, as part of the applicable law, Romania stressed that the set of principles and procedures agreed to by the Parties under Article 4 of the 1997 Additional Agreement were also binding upon the Court as lex specialis. According to Romania, the 1949 Procès-Verbaux, as confirmed by later agreements, had established a 12-nm all-purpose maritime boundary around Serpents' Island, beginning from Point F and ending at Point X as identified by Romania. This, according to Romania, constituted the initial segment of the maritime boundary. The only geographic feature at issue was the presence of Serpents' Island, described by Romania as a small insignificant and uninhabited maritime feature. Romania claimed that under paragraph 4(a) of the 1997 Additional Agreement, the Parties had agreed to apply LOSC Article 121, as applied in State practice and in international case law, and that this indicated their agreement that Serpents' Island was to be treated as a "rock". Moreover, Romania argued in the alternative that notwithstanding LOSC Article 121(6), the jurisprudence of the Court had consistently excluded small islands because they would have a disproportionate effect on the maritime boundary and thus lead to inequitable results.

For the method of delimitation, Romania, relying upon paragraphs 4 (b) and (c) of the 1997 Additional Agreement and the jurisprudence of the Court, requested the Court to employ the equidistance line for adjacent coasts and the median line for opposite coasts, and for the provisional lines to be adjusted, taking into account special/relevant circumstances according to the principle of equity and the method of proportionality, as applied in State practice and the decisions of international courts.

As the relevant base points for its provisional equidistance line, Romania selected the seaward end of the Sulina Dyke on its own coast and the island of Kubansky and Cape Burnas on the Ukrainian coast. In drawing the provisional median line, Romania once again claimed the seaward end of the Sulina Dyke and the outer end of the Sacalin Peninsula and, for the Ukrainian coast, Capes Tarkhankut and Khersones as the relevant base points. Predictably, Romania objected to Ukraine's use of Serpents' Island as a base point on the grounds that it was a rock 
under LOSC Article 121(3), with no entitlement to an EEZ or continental shelf. Romania also tried to exclude it on grounds that Ukraine had not notified it as a base point to the United Nations under LOSC Article 16, and because its use would result in a distortion of the coastline. The central point for Ukraine, of course, was Serpents' Island.

While Ukraine accepted Romania's base points on the Sulina Dyke and Sacalin Peninsula, it nevertheless disagreed with the use of the seaward tip of the Sulina Dyke. For its own coasts Ukraine selected Serpents' Island and the tip of Cape Khersones for drawing the provisional equidistance line (Bystrova, 2007, p. 77). Ukraine brushed aside Romania's argument regarding its failure to have notified the United Nations of Serpents' Island as a base point as not necessary for low-water marks. According to Ukraine, Serpents' Island was relevant as a base point because it had a coast and it was in proximity to the Ukraine mainland.

On the question of which base points would be used for establishing the provisional boundary lines, the Court asserted judicial autonomy rather than defer to the base points as selected by the Parties. Dividing the area into two sectors of adjacency and oppositeness, the Court concluded that because the Romanian coasts were both adjacent and opposite to Ukraine at the same time, the base points to be used for the Romania coasts would be the same. Whereas, in the case of Ukraine, there were two distinct sections of adjacency and oppositeness calling for the use of different base points. The Court further identified as a third step the need to identify a "turning-point" on the equidistance line where the direction of the line would turn and follow a median line of oppositeness.

In selecting the appropriate base points for establishment of the provisional equidistance line, the Court stressed the role of geographic factors. In doing so, the Court concluded that the Sacalin Peninsula, as a landmass that formed part of the Romanian mainland, where the Romanian and Ukrainian coasts are directly opposite to each other, was appropriate as a base point. The Court selected the coordinates of $44^{\circ} 50^{\prime} 28^{\prime \prime} \mathrm{N}$ and $29^{\circ} 36^{\prime} 53^{\prime \prime E}$ as the base points on the Sacalin Peninsula. In regard to the use of the Musura Bay as a base point on the Romanian coast, the Court found it appropriate in light of its forming a prominent point of the Romanian coast in the direction of the Crimea and was in an area where the coasts of the two States were adjacent. These two factors led the Court to conclude their appropriateness for drawing the provisional equidistance line. However, the Court then had to determine whether the seaward end or 
the landward end of the 7.5-km-long dyke would be appropriate to use as a base point for Romania.

The Court rejected Romania's selection of the seaward end of Sulina Dyke as notified by Romania under LOSC Article 16 to the United Nations, and decided instead that the landward end was more appropriate. The Court reached this decision by considering whether Sulina Dyke met the definition of "permanent harbour works" as provided by LOSC Article 11, as claimed by Romania. The Court did not feel it was bound to use the base point as notified to the United Nations under LOSC Article 16, even though Ukraine had not contested the choice at the time but did in its Counter-memorial. The Court made a "fine" distinction between the determination of the baseline for measuring the breadth of the continental shelf and the EEZ under LOSC Articles 7, 9, 10, 12 and 15, and identifying base points for drawing an equidistance/median line, treating these as being two separate issues. The Court explained that the Court was bound by the physical geography of the relevant coasts and not by the base points selected by the States.

\section{The Ukrainian Position (base points)}

In the first sector of adjacency, based on its being the most prominent point of the Ukrainian coast and forming the counter-part of the landward end of the Sulina Dyke on the Romanian coast, the Court identified the south-eastern tip of Tsyganka Island as the first base point for the Ukrainian coast. The Court rejected the Island of Kubansky as the second base point, determining it was irrelevant because it did not produce any effect on the equidistance line drawn in reference to the base point on Tsyganka Island.

In identifying the base points for the sector of the Ukrainian coast opposite to the Romanian coast, the Court chose Cape Tarkhankut as the point where the Crimean coastline juts out significantly and Cape Khersones as the point where the land protrudes out to sea. The coordinates for the base points for the Ukrainian coasts as selected by the Court were Tsyganka Island at $45^{\circ} 13^{\prime} 23.1^{\prime \prime} \mathrm{N}$ and $29^{\circ} 45^{\prime} 33.1^{\prime \prime} \mathrm{E}$, Cape Tarkhankut at $45^{\circ} 20^{\prime} 50^{\prime \prime} \mathrm{N}$ and $32^{\circ} 29^{\prime} 43^{\prime \prime} \mathrm{E}$, and Cape Khersones at $44^{\circ} 35^{\prime} 04^{\prime \prime} \mathrm{N}$ and $33^{\circ} 22^{\prime} 48^{\prime \prime} \mathrm{E}$.

The Court rejected Ukraine's argument to use Serpents' Island as one of its base points on the grounds that the Court was obligated to take into account the national legislation of the States relating to the definition of their territorial sea, which in the case of Ukraine would include the low- 
water mark on the shore of Serpents' Island as a relevant base point. The Court, observing that Serpents' Island did not form a fringe of islands constituting a part of the coastline, concluded that using it as a base point would amount to an unacceptable "judicial refashioning of geography" under both existing law and practice of maritime delimitation.

Ukraine accepted the Court's jurisdiction based on Article 4(h) of the 1997 Additional Agreement, but challenged the scope of the Court's jurisdiction to confirm, as requested by Romania, that a 12-nm all-purpose boundary had been established around Serpents' Island. This exceeded the Court's express and limited jurisdiction to delimit only the continental shelf and EEZ of the Parties. Moreover, Ukraine rejected Romania's claim that the Parties had agreed for the Court to delimit the maritime boundary based on the 1997 Additional Agreement and the existence of any lex specialis. Ukraine countered that the Court was bound only to apply international law as provided for under Article 38 of its Statute and, for purposes of maritime delimitation, those rules as embodied in the relevant provisions of the LOSC. Moreover, Ukraine argued that Serpents' Island was not a "rock", but an "island" under LOSC Article 121. Ukraine, as did Romania, requested the Court to apply the "quidistance/special circumstance" rule, which incorporated the median line and equidistance line for opposite and adjacent coasts, to be adjusted to achieve an equitable solution.

The question of the applicable law in the case centered on two issues: first, whether the five principles agreed to by the Parties in the 1997 Additional Agreement for negotiation of the maritime boundary were binding upon the Court in settling the dispute, and second, whether the 1949, 1963, 1974 Procès-Verbaux constituted "agreements in force" under LOSC Articles 74(4) and 83(4), and had already delimited that part of the maritime boundary surrounding Serpents' Island.

With regard to the first question, Romania argued that the Court was required to apply the five principles listed in Article 4 of the 1997 Agreement as part of LOSC Articles 74(1) and 83(1), as part of what it referred to as the principle of the primacy of agreement. Romania's argument was based on a broad interpretation of the stated provisions, one which encompassed all questions relating to delimitation. Implicit was the question related to the role of the Court following unsuccessful negotiations between Parties. According to Romania, the Court was only stepping into the shoes of the Parties to complete the negotiations where the Parties had been unsuccessful. In particular, Romania stressed the necessary application 
of LOSC Article 121(3), further buttressing its position by arguing that Ukraine's then failure to object to Romania's LOSC Article 310 declaration about the application of LOSC Article 121(3) constituted an acceptance of the Romanian position.

Ukraine disagreed with Romania on both issues and argued that the Court, by virtue of LOSC Articles 74(1) and 83(1), was obliged to decide the case by the application of international law in accordance with Article 38(1) of the Statute of the International Court of Justice. The five principles, according to Ukraine, as stated in the chapeau of paragraph 4 of the 1997 Additional Agreement, were applicable only between the Parties during negotiations. Moreover, the Court was an "autonomous judicial institution, acting in the exercise of its own authority" and not acting on behalf of the Parties after a failed negotiation (Jacovides, 1979, p. 284). Ukraine was, however, quick to note that the principles in question would apply only insofar as "part of the normal rules of international law which the Court will apply". Ukraine further rejected Romania's claim that its declaration made pursuant to LOSC Article 310 had any legal import in the case.

On both counts the Court rejected the Romanian position and favored Ukraine's arguments. In answering the question about the mandatory applicability of the fi ve principles of the 1997 Additional Agreement, the Court looked to the language of the chapeau of paragraphs 4(a) to (e), which expressly referred to the application of the enumerated principles to the negotiation process between the two States, and considered that the Parties only intended that the principles apply to the negotiation process and not to any subsequent third-party adjudication. The Court also drew a temporal line between the dates of 1997, when the Additional Agreement was concluded, and 1999, when the LOSC had entered into effect for both Romania and Ukraine. According to the Court, the LOSC had primacy as the law to be applied in the case. Accordingly, the case was to be decided by LOSC Articles 74(1) and 83(1), respectively. Nevertheless, while the Court rejected the application of the five principles as a function of a binding agreement between the two States, the Court was careful to state that the five principles could be applicable to the extent that they are part of the relevant rules of international law.

The Court further rejected Romania's attempt to use its declaration under LOSC Article 310 as grounds for applying LOSC Article 121(3) to Serpents' Island. The Court recalled that States were free to make declarations under LOSC Article 310, but these had no legal effect on 
the Court, who would only apply the relevant provisions of the LOSC in accordance with its own jurisprudence and Article 31 of the Vienna Convention on the Law of Treaties of 23 May 1969. With regard to the more interesting question of what constituted an agreement for purposes of LOSC Articles 74(4) and 83(4), the Court treated this question as part of the question of the legal nature of the 12-nm arc.

The boundary requested by Romania rested on two fundamental arguments. First, that the 12-nm boundary established around Serpents' Island was an all-purpose boundary agreed to by the Parties by the 1949 General Procès Verbal and confirmed by subsequent agreements. Second, that the Parties in 1949 had agreed to the starting and ending points of the 12-nm boundary, identified by Romania as Points F and X respectively. In its memorial, Romania asked the Court to confirm what Romania described as a 12-nm all-purpose boundary agreed to by the Parties under the 1949 Procès-Verbaux. Romania conceded that the Parties had never determined the geographic coordinates for the 12-nm arc, except for those established by the 2003 Border Regime Treaty marking the final point of intersection of the territorial seas of the two States, but maintained that the language of the 1949 General Procès-Verbal had determined Point X as the final point of the 12-nm arc, and, consequently, the starting point for delimitation of the continental shelf and EEZ between the Parties. Romania went further, arguing that according to international law, as it stood in 1949, the Parties had also effected a delimitation of different legal regimes that included the continental shelf. Notably absent, of course, was an explanation as to how the concept of the EEZ, a concept that was not extant in 1949, would fi $t$ in with this view. Nonetheless, with a rather loose interpretation of international law and the lex lata in 1949, Romania argued that the Parties had intended to both delimit their respective territorial seas in relation to Serpents' Island and establish different maritime regimes.

Ukraine challenged Romania on practically all of these points, beginning with Romania's two-sector approach, which Ukraine described harshly as being "contrived" and "artificial". Ukraine rejected Romania's arguments that the 1949 General Procès-Verbaux had established an allpurpose maritime boundary of the 12-nm arc around Serpents' Island and characterized Romania's attempt to describe the regime of the continental shelf and EEZ as lex lata in 1949 as "bold". According to Ukraine, the 1949 Procès-Verbaux had only established a partial State border between Romania and the USSR. 
At the time, Romania had only a 6-nm territorial sea and not a $12-\mathrm{nm}$ territorial sea, as was the case for the USSR. Only in 2003, under the Border Regime Treaty, did the Parties establish a border marking the Point where their respective 12-nm territorial seas intersected. According to Ukraine, the 12-nm arc had only demarcated the exterior margin of the Soviet maritime boundary without determining the regime and, accordingly, there had been no delimitation of the territorial seas of both States. According to Ukraine, the area beyond the southern projection of the 12-nm arc was high seas and not Romanian waters (Riezkov, 2009). For this reason, Ukraine challenged Romania's request to the Court to confirm the 12-nm arc as a delimitation of the territorial seas of the two Parties on the grounds that the Court would be exceeding its jurisdiction.

The legal status of the 12-nm arc was important for the Court as it would determine the starting point for the drawing of the final single-purpose maritime boundary. The Court examined the language of the relevant treaties and maps and found no documentary support for the Romanian position that the 1949 General Procès-Verbal and subsequent agreements had established an all-purpose maritime boundary that ended at Point X. The Court found that Romania's reliance on the imprecise terminology of "from" and "goes on the exterior margin of the marine boundary zones" was insufficient to support Point $\mathrm{X}$ as the end-point of an agreed all-purpose maritime boundary. The fact that no precise coordinates had been included in any of the instruments until the 2003 Border Agreement was significant for the Court and a reason for rejecting Romania's argument. The Court noted that it was not until the 1997 Additional Agreement that the parties made express reference to the EEZ and the continental shelf, and then, the Court pointed out, this was only in the context of providing the process for creating a boundary and not actually establishing the boundary perse. The Court concluded that there was no agreement in force between the parties delimiting the continental shelf and EEZ and that the 1949 agreements had only effected a demarcation of the State border between Romania and the USSR.

The Court further rejected Romania's argument that the 1949, 1963 and 1974 Procès-Verbaux and the 1997 Additional Agreement constituted "agreements" for the delimitation of the continental shelf and the EEZ as provided for by LOSC Articles 74(4) and 83(4) respectively. It adopted a conservative interpretation of these provisions, noting that the pre-1997 agreements made no reference to the continental shelf or EEZ. The Court 
also observed that the 1949 Procès-Verbaux pre-dated the recognition of the continental shelf under international law and the development of the concept of an EEZ, thereby rejecting Romania's tenuous lex lata argument. In its judgment, the Court made it clear that in order for an agreement to fall under LOSC Articles 74(4) and 83(4), its language would have to expressly indicate such a purpose. The Court also made it clear that, absent any express statement of intention by Parties that an agreement for delimitation of the continental shelf and EEZ is to apply to any subsequent adjudicative proceedings, agreements concluded before the entry into force of the LOSC will be subordinated to the LOSC.

\section{The key outcome based on the results of controversy}

One issue that was intertwined with the question of the 12-nm arc involved the sole jurisdictional challenge raised by Ukraine. In principle, the jurisdiction of the Court was uncontested by both Parties. The 1997 instruments and the 2003 Border Regime Treaty had established the basic foundation of the Court's jurisdiction. The Parties agreed that after twentyfour unsuccessful rounds of negotiations a stalemate had been reached and that the Court had jurisdiction to delimit the continental shelf and EEZ between the two Parties, but not their territorial seas. However, Ukraine objected to the Court's jurisdiction on the grounds that if the Court confirmed the 12-nm all-purpose boundary as requested by Romania, this would entail delimitation of the territorial seas, thereby exceeding the Court's jurisdiction.

In addressing this question, the Court began by examining the object and purpose of the 1997 Additional Agreement, also taking into account the 1997 Treaty on Good Neighborliness and Co-operation between Romania and Ukraine. Accordingly, the Court concluded that the intention of the two States had been to resolve all problems of delimitation on both land and sea in a comprehensive way, but that in accordance with the State Border Regime Treaty 2003, the Court's jurisdiction was limited to delimitation of the EEZ and continental shelf of the two States. Nevertheless, stepping outside the boundaries of these treaties, the Court exercised sua sponte a competence of a limited but nonetheless significant nature, granting itself a margin of discretion to delimit a portion of the territorial sea of the Parties, stating that "contrary to what has been suggested by Ukraine, nothing hinders that jurisdiction from being exercised so that a segment of the line may result in a delimitation between, on the one hand, 
the exclusive economic zone and the continental shelf of one State, and, on the other hand, the territorial sea of the other State at its seaward limit". The Court rejected Romania's argument, but also rejected Ukraine's restrictive depictions of the Court's competence in drawing maritime boundaries.

Identification of the relevant coasts was the key to the drawing of the final maritime boundary in this case. In identifying the relevant coasts of the two Parties, the Court stated that according to the principle that "the land dominates the sea", the coast of the State is "the decisive factor for title to submarine areas adjacent to it." The Court further explained that "the task of delimitation consists of resolving the overlapping claims by drawing a line of separation of the maritime areas concerned." Consequently, the identification of the relevant coasts would determine the area of delimitation and also the equitable question of assessing any disproportionate length between the coasts of the States. Ukraine's claim relied particularly on the latter factor and for this reason it was important for Ukraine to claim a lengthy coastal area. According to Romania its entire coastal area was relevant. Romania adopted a two-sector approach for drawing the delimitation boundary for the continental shelf and EEZ by separating the area to be delimited into two sectors. The first sector was identified as the area of adjacency between the two mainland coasts and the second sector was the area where the two mainland coasts were opposite. Romania, citing the Court's decision in the Tunisia/Libya Continental Shelf case, determined the relevant coast based on the principle of natural prolongation of the maritime areas and overlap of maritime projection.

In the first sector, Romania drew an equidistance line that was qualified by the 12-nm arc drawn around Serpents' Island following an easterly direction until reaching the median line drawn between the opposite coats of the Parties. The second sector, as drawn by Romania, followed a southerly direction until it reached the Turkish and Bulgarian boundaries, implicating possible rights of third States. According to Romania, the boundary in the first sector was based upon the agreements in force between the Parties, including the applicable principles in paragraph 4 of the Additional Agreement 1997, with particular reference to LOSC Article 121, the character of Serpents' Island as a rock under LOSC Article 121(3) and other relevant circumstances.

For Sector 1, Romania drew an equidistance maritime boundary line between the continental shelf and the EEZ of both Parties that began from Point F $\left(45^{\circ} 05^{\prime} 21^{\prime \prime} \mathrm{N}, 30^{\circ} 02^{\prime} 27^{\prime \prime} \mathrm{E}\right)$, the intersection point of their 
territorial seas, as agreed by the 2003 Border Regime Treaty, and then continued along the segment of the arc having a radius of $12 \mathrm{~nm}$ drawn from Serpents' Island and then up to Point X (45 $\left.14^{\prime} 20^{\prime \prime} \mathrm{N}, 30^{\circ} 29^{\prime} 12^{\prime \prime} \mathrm{E}\right)$. From Point $\mathrm{X}$, the terminus point of the 12-nm arc, the boundary joined the equidistance line based on the adjacent coasts of Ukraine and Romania at Point Y $\left(45^{\circ} 11^{\prime} 59^{\prime \prime} \mathrm{N}, 30^{\circ} 49^{\prime} 16^{\prime \prime} \mathrm{E}\right)$. The boundary then proceeded as the equidistance line, going through Point D $\left(45^{\circ} 12^{\prime} 10^{\prime \prime} \mathrm{N}\right.$, $\left.30^{\circ} 59^{\prime} 46^{\prime \prime} \mathrm{E}\right)$ and up to Point $\mathrm{T}$, which was the turning point into the median line $\left(45^{\circ} 09^{\prime} 45^{\prime \prime} \mathrm{N}, 31^{\circ} 08^{\prime} 40^{\prime \prime} \mathrm{E}\right)$. In the second sector, Romania drew a median line between the opposite coasts of the Parties lying between the Romanian coastline and the Crimean Peninsula coast and then in a southerly direction towards Bulgaria and Turkey, from Point $\mathrm{T}$ to Point Z (4326’50"N, 31²0’10"E).

Ukraine challenged Romania's two-sector approach and division of the area to be delimited between "opposite" and "adjacent" coasts and accused Romania of double counting its coastal lengths. Otherwise, there was little disagreement over the relevant Romanian coast. Where the Parties differed was in determining the relevant coastal area of Ukraine, who argued for a three sector approach that would include its entire coastal area, amounting to a total length of $1,058 \mathrm{~km}$. Romania countered that the area between the Nistru/Dniester River (point S on Romania's map) and Cape Tarkhanhut along the northern segment, especially the Karkinits'ka Gulf should be excluded, as it did not constitute an opposite or adjacent coast which reduced the total relevant Ukraine coastal area to $388.14 \mathrm{~km}$ (Dmytrychenko, 2006, p. 375). There was some disagreement as to whether Ukraine had included Serpents' Island as part of its relevant coast. Romania claimed that Ukraine had not included it, whereas Ukraine claimed that it had included the island as part of its geographical context.

Ukraine drew an equidistance line, which was partly a "strict" equidistance line in the area where the coasts are adjacent, and partly a "strict" median line between opposite coasts, and gave full effect to the relevant basepoints, including Ukraine's Serpents' Island. Based on the application of the equitable principles/relevant circumstances rule, Ukraine claimed a 5:1 ratio in coastal lengths in its favor, making some adjustments.

The final maritime boundary line requested by Ukraine was described as beginning from the co-ordinates of $45^{\circ} 05^{\prime} 21^{\prime \prime} \mathrm{N}$; $30^{\circ} 02^{\prime} 27^{\prime \prime} \mathrm{E}$, then extending in a south-easterly direction to Point $2\left(44^{\circ} 54^{\prime} 00^{\prime \prime} \mathrm{N} ; 30^{\circ} 06^{\prime} 00^{\prime \prime} \mathrm{E}\right)$, and then to Point $3\left(43^{\circ} 20^{\prime} 37^{\prime \prime} \mathrm{N} ; 31^{\circ} 05^{\prime} 79^{\prime \prime} \mathrm{E}\right)$, continuing along the same 
azimuth, until the boundary reached a point where the interests of third States potentially came into play.

To identify the relevant coasts, the Court began by first ascertaining the relevant coastal sectors in Ukraine where there was agreement between the Parties. This included the coast of the Crimea Peninsula between Cape Tarkhankut and Cape Sarych, and the area running from their common border to Nistru/Dniester Firth (Point S on Romania's map). The Court proceeded next to identify the relevant coastal area in Ukraine disputed by the Parties, which the Court determined to be the coast extending from Point S to Cape Tarkhankut. In doing so, the Court recalled two principles: first, the oft-cited principle pronounced by the Court in the North Sea Continental Shelf cases that the "land dominates the sea" in such a way that coastal projections in the seaward direction generate maritime claims, and second, that for purposes of maritime delimitation, the relevancy of a coast was conditional on the principle of non-encroachment and overlap of coastal projections. Coasts that did not project overlapping maritime zones would be excluded from being considered as "relevant" for purposes of delimitation (Dmytrychenko, 2006, p. 375). Neither Party had disagreed with these principles, but rather differed in the technical implementation and calculation of the areas of coastal projection and overlap. Noting that the coasts in question faced each other and that their submarine projections did not overlap with those of Romania, the Court excluded the Karkinits'ka Gulf and the coastline of the Yahorlys'ka Gulf and Dnieper Firth, thereby reducing the total length of the relevant Ukrainian coast to $705 \mathrm{~km}$ from Ukraine's calculation of 1,058 km50 and the ratio for the coastal lengths to 1:2. from Ukraine's calculation of 1:4.1. On the other hand, the Court found that the area of Ukraine projecting southward between Cape Tarkhankut and Point S did overlap with Romania and accordingly would be considered as being relevant. Striking its fi rst blow to Ukraine's hopes of using Serpents' Island as a relevant factor, the Court excluded its coastal area as being too short to make any difference-third of what Ukraine had argued for, which in turn had a negative impact on Ukraine's argument for a larger marine area based on the disproportionate lengths between the coasts of the two States.

The Parties disagreed as to what constituted the relevant maritime area to be delimited. Romania based its argument upon certain coastal projections, noting that the first three of five such projections were subject to disagreement between the parties. First, the northern coastal area from 
Point S to Cape Tarkhankut was not relevant. Second, the south-western relevant area was identified as bordering the equidistance line between the adjacent Romanian and Bulgarian coasts, as well as the median line between the opposite Romanian and Turkish coasts, and the delimitation agreed to between Turkey and the former USSR to which Ukraine had succeeded. Consideration of this could prejudice the interests of third States not party to the proceedings. Third, in the south-east, the relevant area was bordered by the meridian uniting Cape Sarych with the delimitation boundary between Ukraine and Turkey. This formed part of the relevant area. Finally, in the west and east the relevant areas were formed by the relevant coasts of Romania and Ukraine.

Ukraine argued for inclusion of the western area corresponding to the coastline between the land boundaries with Bulgaria and Ukraine and the stretch of the Ukrainian coast extending from the border with Romania until a point located just north of Odessa. In the north, Ukraine included the south-facing Ukrainian coast, and in the east the west-facing Crimea Peninsula terminating at Cape Sarych. Ukraine bordered the southern area with a perpendicular line drawn from the mainland coast from the point where the Bulgarian and Romanian land borders reach the Black Sea, until a point between the Romanian and Ukrainian coasts where the interests of third States potentially come into play. This point is then connected to Cape Sarych by a straight line which would be the south-eastern limit of the relevant area. In respect of the three disputed areas, Ukraine considered the first to be a relevant area, the second to be relevant in part, and the third to be discounted as it was subject to a prior delimitation agreement between Ukraine and Turkey.

The Court first noted that the identification of the "relevant area" was part of the methodology of maritime delimitation. Furthermore, the relevant area is pertinent to checking disproportionality, which the Court, in reference to Ukraine, noted was not a method of delimitation, but rather a "means of checking whether the delimitation line arrived at by other means needs adjustment because of a significant disproportionality in the ratios between the maritime areas which would fall to one party or other by virtue of the delimitation line arrived at by other means and the lengths of their respective coasts." The Court reiterated the principle, first announced in the North Sea Continental Shelf cases, that the object of delimitation is not equal apportionment of the maritime area, but intended to produce an equitable delimitation. 
Beginning with the northern section, the Court identified the relevant area as that part of the Ukrainian coast lying to the north of the line running from Point S to Cape Tarkhankut and the area lying immediately south of this section, excluding the Karkinits'ka Gulf. As to the southern limit of the relevant maritime area, based on the view that the area identified was only an approximation of overlapping areas between the Parties, the Court did not find it necessary to take into account potential third-party interests, and decided that both the south-western and south-eastern triangles, as claimed by Romania, constituted the relevant maritime area for purposes of measuring proportionality.

In a rather curt statement, with a notable absence of reference to customary international law or general principles of international law, the Court began the process of delimitation by stating that "when called upon to delimit the continental shelf or exclusive economic zones, or to draw a single delimitation line, the Court proceeds in defined stages". With specific reference to the Continental Shelf (Libyan Arab Jamahiriya/Malta) case, the Court stated that the first stage was the establishment of a provisional delimitation line based on geometrically objective and geographically appropriate methods. Although the Court had decided that it was not bound by the principles adopted by the Parties under the 1997 Additional Agreement, the Court proceeded to apply the equidistance approach for adjacent coasts and the median-line approach for opposite coasts, as included in paragraph 4 of the 1997 Additional Agreement. The Court stated that the equidistance line was to apply unless "there were compelling reasons that make this unfeasible in a particular case" with specific reference to the Territorial and Maritime Dispute between Nicaragua and Honduras in the Caribbean Sea (Nicaragua v. Honduras) (Baibekova, 2012, p. 72).

The second stage, explained the Court, involved the identification of relevant factors calling for the adjustment of the provisional line in order to achieve an equitable result, and the third stage involved verification that the provisional line did not result in an inequitable solution by reason of any marked disproportion between the ratio of the coastal lengths and maritime areas of the Parties. The Court further emphasized the importance of using protuberant coastal points close to the delimitation area in constructing the median and equidistance lines. In addition, the Court recognized the priority of the physical geography of the coasts over the Parties' choice in selecting base points for drawing the provisional equidistance line and the use of the most seaward point of the two coasts. 
Ukraine was unsuccessful in its claim to adjust the provisional equidistance line towards the Romanian mainland based on the disparity between the lengths of the relevant coasts as a relevant factor. In its approach, the Court in essence identified three principles for applying the "disproportion" or "disparity" of coastal lengths test. First, the difference in the lengths of the coasts had to be "marked" or "substantial." Second, the Court emphasized the discretionary aspect of using disproportion of coastal lengths as a reason to adjust the provisional equidistance line. Third, the determination of whether the disparity in coastal lengths as a relevant factor was not a mathematical equation. In this case, the Court found that a ratio of 1:2. did not constitute a significant disparity of coastal lengths between the Parties, in contrast to the Jan Mayen case where the ratio was 1:9, and in the Libya/Malta case, where the ratio was 1:8. The Court concluded that the disparity between the Ukraine and Romanian coasts was not marked enough to adjust the provisional equidistance line. Whether the Court would have decided otherwise if it had accepted Ukraine's calculation of total relevant coastal area with a ratio of 1:4. remains an open question. Nevertheless, even Ukraine's calculation was significantly less than that in the Jan Mayen and Libya/Malta cases.

Romania raised a novel argument in calling for the Court to treat the enclosed nature of the Black Sea as a relevant/special circumstance. Romania argued that the interests of equity would require the Court to apply the same methodology of delimitation as applied by the other riparian Black Sea States. Ukraine challenged the Romanian assertion as having no basis in law or State practice. The Court noted that the agreements concluded between Turkey and the USSR in 1976, and the Exchanges of Notes in 1986 and 1987 which used the same coordinates for establishing their continental shelf, would be used in establishing their EEZ. The Court further noted the agreement concluded between Turkey and Bulgaria on the determination of the boundary in the mouth area of the Rezovska/ Mutludere River and the delimitation that was concluded in 1997.

The Court did not reject outright Romania's argument, but simply stated that it would "bear in mind" the agreements between Turkey and Bulgaria, and between Turkey and Ukraine, in determining the endpoint of the single maritime boundary line. Moreover, the Court concluded that neither the delimitation agreements in question nor the enclosed nature of the Black Sea required adjustment of the provisional equidistance line. 
Advancing a broad interpretation of LOSC Article 121(3), Romania argued that the small size of Serpents' Island, together with its physical characteristics, rendered it inhospitable to support human or economic life, which thereby qualified it as a rock under LOSC Article 121(3). Romania cited a number of factors, such as the island's geological composition as a rock formation, the lack of water resources other than rainfall, lack of soil and vegetation, and its inability to sustain human or economic life of its own. Romania supplemented its argument with historical, literary, scientific and other independent third-party evidence that described Serpents' Island as a rock. Romania also included quotations from Ukrainian publications describing Serpents' Island as a rock. However, in 2003 a number of Ukrainian newspaper articles began to write about the topographic transformation of Serpents' Island. Apparently, Ukrainian officials had been transporting fertile soil to the island and planting trees, shrubs and flowers. Romania offered a definition of human habitation as being capable of "sustaining human groups steadily rooted and organized", and which "have the intention to establish there a much more global connection". Romania argued that human life must be capable of being sustained by the maritime formation itself and not by external support. Romania offered as precedent the exclusion of the islet Fil a by the Court in the Libya/Malta case, where the Court described it as an "uninhabited rock".

Ukraine, on the other hand, beginning with the obvious argument of the Serpents' Island name itself, enumerated several cases of State practice where bilateral agreements had given full effect to small and uninhabited islands, and other islands that were either small in size, or had a small or zero population. Moreover, Ukraine noted the vague language of LOSC Article 121(3). According to Ukraine, the definition of an "island" in LOSC Article 121(2) implicitly included a "rock" under LOSC Article 121(3). Ukraine continued, arguing that the term "rock must be understood as a small and insignificant feature composed essentially of material commonly regard as rocky, in contradistinction to an 'island' which is an altogether larger and more substantial feature". Ukraine further noted an ambiguity in the language of LOSC Article 121(3), and whether the conditions for defining a "rock", were in the disjunctive or conjunctive. Ukraine was of the view that the conjunctive applied, requiring that a rock be both unable to sustain human habitation and economic life of its own. Moreover, Ukraine noted the ambiguity as to what was meant by "human habitation" and "economic life of its own", 
and whether this included some dependency on outside assistance. If so, then many large and populated islands could be deemed to be "rocks". Nevertheless, Ukraine asserted that Serpents' Island was able to and did sustain human habitation, conceding by silence that it did not sustain an economic life of its own.

The Court declined to address the question of when a geological formation could be legally considered to be a "rock" under LOSC Article 121(3). Instead, the Court looked at the geographical configuration, and Serpents' Island's proximity to Ukraine's mainland coast in the area of the Danube Delta. Based on where the Court had drawn the southern tip of the provisional delimitation line, it concluded that Serpents' Island could not project maritime entitlements greater than Ukraine's mainland. The Court further noted that the eastward projections of Serpents' Island, were fully subsumed by the western and eastern mainland coasts of Ukraine. Moreover, the Court calculated that even in the case that Serpents' Island was capable of projecting a continental shelf and EEZ, these would not extend further than the entitlements generated by the mainland coast of Ukraine based on the southern limit of the delimitation area identified by the Court, and that any potential entitlements generated by Serpents' Island in the eastern and western direction would fall within the maritime entitlements of the Ukrainian mainland. Accordingly, the Court stated that even in the hypothetical instance that Serpents' Island was not a rock, but did fall under LOSC Article 121(2), it would have no impact beyond the zones generated by the Ukrainian mainland, rendering its effect null or irrelevant. As a result, the Court decided that the role of Serpents' Island was essentially irrelevant and there was no need to address the question of whether it was a "rock" or an "island" under LOSC Article 121.

As to the effect of activities of the Parties, such as granting oil and gas concession licenses, and regulating fishing activities (including enforcement), the Court declined to attribute any role to these factors, reiterating the observation of the Arbitral Tribunal in the case between Barbados and Trinidad to treat resource-related activities more cautiously as relevant circumstances. The Court concluded that the provisional equidistance line it had drawn was equitable as it had avoided the problem of a cutting-off effect on the entitlements of the other States, which it observed had been the result of provisional equidistance lines as proposed by, respectively, Ukraine and Romania. 
Likewise, the Court also discounted Ukraine's and Romania's claim of security interests as relevant circumstances requiring adjustment of the provisional equidistance line.

The Court fixed the starting point (Point 1) at the meeting points of the Parties' territorial seas, as agreed to under the 2003 Border Regime Treaty, at the coordinates of $45^{\circ} 05^{\prime} 21^{\prime \prime} \mathrm{N}$ and $30^{\circ} 02^{\prime} 27^{\prime \prime E}$. From Point 1 the Court drew a line that followed the 12-nm territorial sea of Serpents' Island until it intersected Point 2 at the coordinates of $45^{\circ} 03^{\prime} 18.5^{\prime \prime} \mathrm{N}$ and $30^{\circ} 09^{\prime} 4.6^{\prime \prime} \mathrm{E}$ and with a line equidistant from their respective adjacent coasts as indicated by the base points at the landward end of Sulina Dyke and the south-eastern tip of Tsyganka Island. Continuing from Point 2, the Court's line continued along the equidistance line in a south-easterly direction until Point 3, located at the coordinates of $44^{\circ} 46^{\prime} 38.7^{\prime \prime} \mathrm{N}$ and $30^{\circ} 58^{\prime} 37.3^{\prime \prime} \mathrm{E}$, continuing in the same south-easterly direction along the equidistance line to Point 4 at the coordinates of $44^{\circ} 4^{\prime} 13.4^{\prime \prime} \mathrm{N}$ and $31^{\circ} 10^{\prime} 27.7^{\prime \prime} \mathrm{E}$. From Point 4 the boundary follows the equidistance line to Point 5 at the coordinates of $44^{\circ} 02^{\prime} 53.0^{\prime \prime} \mathrm{N}$ and $31^{\circ} 24^{\prime} 35.0^{\prime \prime} \mathrm{E}$, and then moves in a southerly direction beginning at a geodetic azimuth at the coordinates of $185^{\circ} 23^{\prime} 54.5^{\prime \prime}$ until the boundary reaches the area where rights of third States may be implicated.

The Judgment brought to a conclusion the long-standing controversy over Serpents' Island for purposes of maritime delimitation, a matter that had been a subject of negotiation dating back to the time of the former USSR. The Romania/Ukraine judgment marks a valuable contribution to the development of international law of maritime delimitation. The Court's methodical application of a three-stage delimitation process of drawing a provisional equidistance line, then making adjustments based on relevant factors, and applying the proportionality test to ensure the line achieved an equitable result, demonstrates the progress made since the time when the Court had to grapple with the questions as to whether the drawing of a provisional equidistance line was a principle of customary international law or not, and what factors would be included to achieve an equitable result. In making reference to what it termed as "settled jurisprudence on maritime delimitation", the Court drew a single-purpose maritime boundary delimiting the continental shelf and EEZ between Romania and Ukraine without the need to rely on the edifice of the principles agreed to by the Parties in the 1997 Additional Agreement.

The key to the final outcome was determining the relevant coasts of the States, which quite simply included only those areas of overlapping coastal 
projections of the continental shelf and the EEZ, and excluded those areas that did not overlap. In applying this method the Court excluded a significant portion of Ukraine's claimed relevant coastal area of the Karkinits'ka Gulf and the coastline of the Yahorlys'ka Gulf and Dnieper Firth. This reduced Ukraine's relevant coastal area and may have undermined Ukraine's argument for adjustment of the provisional boundary based on disproportionality. The Court's calculated ratio of coastal proportion of 1:2 was significantly less than Ukraine's ratio of 1:4. Moreover, the Court made clear that the disparity of coastal lengths as an equitable reason to adjust the provisional delimitation line was not mandatory but discretionary. The implication for future cases may be that the Court will be reluctant to make adjustments unless the disparity was similar to that in the Jan Mayen or Libya/Malta cases. Overall, however, the simplicity of the geography in the present case required no adjustments be made to the original provisional line drawn by the Court, which essentially rejected all claims of special circumstances claimed by the Parties. The final boundary as drawn by the Court almost perfectly apportioned in half the delimitation area as drawn by the Parties in their respective maps. Romania succeeded in excluding Serpents' Island and Ukraine succeeded in excluding the Point $\mathrm{X}$ as the questionable final point for the 12-nm arc around Serpents' Island. It can be concluded that the final maritime boundary resulted in an equitable division of the contested area between the two Parties.

The case also marked the first occasion that the Court has been expressly asked to address LOSC Article 121(3). During the Third Conference on the Law of the Sea, the negotiations generated many different draft texts, some of which included submissions by Romania that clearly had Serpents' Island in mind. The debate over islands and rocks during the Conference is not surprising given that some of the most contentious disputes in the law of the sea involve islands and rocks covering a wide range of geography from the South Asian and China Seas to the Mediterranean and Caribbean Seas. The vague language of LOSC Article 121(3) has been described by noted authors as "poorly drafted", and developing an objective and clear legal definition or distinction between "islands" and "rocks" remains one of the more challenging issues in law of the sea and delimitation cases. As much as this aspect of the Court's Judgment is a disappointment, the Court has nevertheless demonstrated a consistent approach to denying even partial effect to a small maritime feature such as Serpents' Island. In a number of cases the Court has excluded maritime features when drawing a 
single-purpose maritime boundary that could have been defined as "rocks" under LOSC Article 121(3). In each case the Court made no reference to the legal status of the maritime feature, relying instead on equitable factors such as disproportionality or geographic configuration to reach a decision. For example, Kwiatowska, making reference to Judge Schwebel's Separate Opinion in the Jan Mayen case, observed that LOSC Article 121(3) could have played an important role. Likewise, in the second phase of the Eritrea/ Yemen case, in drawing the median line, the Tribunal excluded the small island of Jabalal-Tayr and the Zubayr group of islands, having described them as "barren and inhospitable". There was no discussion, however, as to whether the islands could be defined as "rocks" under LOSC Article 121(3). Similarly, in its merits judgment in the Bahrain / Qatar case, the Court was asked to determine the sovereignty of various islands, islets, low-tide elevations and rocks, including Qit'al Jaradah and Fasht al Jarim, two small uninhabited maritime features without vegetation. The Court had to decide whether the latter two were low-tide elevations or islands under the LOSC. The Court concluded the former to be an island and the latter to be a low-tide elevation, and in both cases excluded them from having any effect on the final boundary line.

The Court excluded Qit'al Jaradah on the grounds of special circumstances, namely that as an insignificant maritime feature, measuring 12 meters by 4 meters at high tide and 600 meters by 75 meters at low tide, it would have a disproportionate effect. The Court, however, made no reference to LOSC Article 121(3). Whereas, given the very small size of Qit'al Jaradah, the Court could have addressed the question of how small maritime features are to be distinguished from LOSC Article 121(3) "rocks".

Another interesting question raised in the present case pertains to the definition of a maritime delimitation agreement under LOSC Articles 74 and 83. Here the Court adopted a conservative position, restricting such agreements to include only those that expressly made such an intention clear on the face of the agreement. It further placed a temporal restriction on the application of agreements concluded prior to the entry in effect of the LOSC for both Parties. The Court's requirement that a delimitation agreement under LOSC Articles 74 and 83 state clearly its application to a specific delimitation procedure is consistent with past decisions, such as the Jan Mayen case. In that case the Court rejected Norway's argument that a 1965 bilateral agreement for delimitation of the continental shelf 
between the Parties was general in its effect and would also apply to the delimitation between Greenland and Jan Mayen.

\section{Conclusions}

As for my opinion about conflict between Ukraine and Romania. This is a territorial dispute with Romania, namely, the Black Sea shelf. In the event that the International Court located in The Hague recognized Snake Island (as it is designated on Ukrainian maps), we would have a monopoly on the development of oil and gas on the shelf. If a piece of land would be called a rock, as assured in Bucharest, access to them would have been at the disposal of Romania. Both sides hoped for a different outcome of this case, but this decision, which was followed, was not expected by anybody. Serpent's Island can not be considered part of the coastal line of Ukraine in determining the middle line in the delimitation of the continental shelf and the exclusive economic zone. Accounting for the island would mean a legal review of the geography.

The Black Sea shelf was in charge of both countries-pretenders, although Serpent's Island was recognized as an island. So, the solution turned out to be twofold. Our rights to the shelf are now lost, nevertheless, the efforts of domestic diplomats for many years have been crowned with success. It is very important that the last problematic situation is removed from the Ukrainian-Romanian relations. The line is a compromise, and the court decision is binding for both parties. According to the parliamentarian, the International Court of Justice adopted an exclusively political decision. It is possible that the main reason for the verdict of the Hague court was the refusal of Kiev to cooperate with the American investor - Vanco in the development of the underwater shelves. Say, as long as Romania is a more reliable partner than we, then it will get the right to develop. Although experts and political scientists believe that the logic of "who will quickly master, that and give the shelf" for the International Court is too primitive. The decision of the International Court deprived Kiev of solid reserves of oil and gas. According to one data, it is about 14 thousand square kilometers of territory, 10 million tons of black gold and 10 billion cubic meters of gas, on the other - there is much more blue fuel there. In this case, the reserves of minerals would be enough for ten years. No one knows how great the shelf potential near Serpent's Island is. Exploration has not yet been carried out at a sufficiently deep level, careful research, too. But there is no need to talk about any colossal deposits in this case. 
The experts analyzed the actions of the domestic Ministry of Foreign Affairs and named three errors committed by the department in the case "Ukraine-Romania" in the International Court of Justice.

The first: when Bucharest asked for NATO and the EU, which did not allow territorial problems among the member states, Kiev managed to persuade the Romanian side to draw up a document that would cancel any claims to Ukraine. But only on land. That there was a solid oil and gas offshore in the Black Sea, then no one knew. As soon as Romania changed power and Traian Besesku became the president, the government immediately remembered this shortcoming of our side and rushed into the attack. The second: the Ministry of Foreign Affairs failed to create an agency under the EU and the Council of Europe, informing and lobbying the interests of our state. As a result, the European media on all the crusts cheated "greedy" Kiev, without even bothering to hear our position. But in the decision-making process, judges rely, among other things, on public opinion. The third: Ogryzko's assurances that Ukraine has better arguments and the "team is much more experienced than Romanian" hid the real picture: the complete absence of the so-called argumentation base. For example, our side could bring a similar territorial conflict between Turkey and Greece as an argument and win, but it did not.

\section{REFERENCES}

Baibekova, L.S. (2012). About differentiation of an exclusive economic zone and a continental shelf between the states. The Law and time, 2(134), 70-73.

Bystrova, A.R. (2007). Do pytannia pro mizhnarodno-pravove rozmezhuvannia morskykh prostoriv u raioni ostrova Zmiinyi [To the question of international legal separation of maritime spaces in the area of Snake Island]. Zovnishnia torhivlia: pravo i ekonomika. [Foreign Trade: Law and Economy], 2 (31), 76-80. [in Ukrainian].

Convention on the Territorial Sea and the Contiguous Zone, 1958 (United Nations). Treaty Series, 516, 205. Retrieved from: https://treaties.un.org/pages/ViewDetails.aspx?s$\mathrm{rc}=$ TREATY\&mtdsg_no=XXI-1\&chapter=21 (2019, October, 15).

Convention on the Continental Shelf, 1958 (United Nations). Treaty Series, 499, 311. Retrieved from: https://legal.un.org/ilc/texts/instruments/english/conventions/8_1_1958_ continental_shelf.pdf (2019, October, 15).

Convention on the Law of the Sea, 1982 (United Nations). The official website of UN. Retrieved from: http://www.un.org/depts/los/convention_agreements/texts/unclos/ unclos_e.pdf (2019, October, 15).

Dmytrychenko, I.V. (2006). Pryntsypy morskoi delimitatsii u vyznachenni kordoniv Ukrainy v Chornomu ta Azovskomu moriakh [Principles of maritime delimitation in deter- 
mining the borders of Ukraine in the Black and Azov seas]. In: Denysova, V.N. (ed.) (2006). Vzaiemodiia mizhnarodnoho prava z vnutrishnim pravom Ukrainy [Interaction of international law with the internal law of Ukraine]. K.: Yustiniana, 374-398. [in Ukrainian].

Dohovir pro vidnosyny dobrosusidstva i spivrobitnytstva, 1997 (Ukraina, Rumuniia). [Agreement on relations of good neighborliness and cooperation between Ukraine and Romania, 1997] Ofitsiynyy sayt Verkhovnoyi Rady Ukrayiny. [The official website of the Verkhovna Rada of Ukraine]. Retrieved from: https://zakon.rada.gov.ua/laws/ show/642_003 [in Ukrainian].

Harina, O. (2009). Protses: "Rumuniia proty Ukrainy": sprava pro rozmezhuvannia morskykh prostoriv mizh Ukrainoiu ta Rumuniieiu v Chornomu mori [Romania $v$ Ukraine: The Case of Delimiting Maritime Spaces between Ukraine and Romania in the Black Sea]. Yurydychnyi avanhard. [Legal Vanguard], 1, 220-225. [in Ukrainian].

Jacovides, A.J. (1979). Three aspects of the Law of the Sea: icelands, delimitation and dispute settlement. Marine Policy, 3, 4, 278-288.

Riezkov, M.I. (2009). Ukrainsko-rumunskyi konflikt navkolo ostrova Zmiinyi. Retrospektyvnyi analiz [The Ukrainian-Romanian conflict over Snake Island. Retrospective analysis]. Problemy mizhnarodnykh vidnosyn. [Problems of international relations], 15. Retrieved from: http://vmv.kymu.edu.ua/v/09/15.htm [in Ukrainian].

Vienna Convention on the Law of Treaties, 1969 (United Nations). Treaty Series, 1155, 331. Retrieved from: https://legal.un.org/ilc/texts/instruments/english/conventions/1_1_1969. pdf (2019, October, 10).

Vienna Convention on Succession of States in respect of Treaties, 1978 (United Nations). Treaty Series, 1946, 3. Retrieved from: https://legal.un.org/ilc/texts/instruments/english/ conventions/3_2_1978.pdf (2019, October, 17).

\section{АНОТАЦІЯ}

Варикаша І. О. Справа щцодо делімітації у Чорному морі (Румунія проти Украӥни). Дослідження позицій.-Стаття.

У даній статті автором було вивчено матеріали про розмежування морських просторів, що були підготовлені за згодою відповідних держав Міжнародним судом ООН. Обрання тематики дослідження було обумовлене конкретною метою - показати те, яким чином Міжнародний суд ООН інтерпретував договірні джерела міжнародного морського права, як він визначив діючі звичаєві правові норми та принципи, та застосовував міжнародне право щодо розмежування морських просторів суміжних держав. Також було досліджено, яким чином відповідні чинники були враховані у конкретних спорах про делімітацію морських просторів та викладені у якості міжнародно-правових аргументів. Крім того, вивчення матеріалів розгляду справи дало можливість визначити правові позиції держав щодо проблем розмежування морських просторів та вивчити міжнародноправову оцінку таких позицій Міжнародним судом ООН. Автор підсумовує, що спір між Україною та Румунією $є$ територіальним спором щодо розмежування 
шельфу Чорного моря. У випадку, якщо Міжнародний суд ООН визнав би о. Зміїний саме островом (як він позначений на українських картах), Україна мала б монополію на розробку нафти та газу на шельфі. Якби ця ділянка землі була би визнана скелею, як запевняла Румунія, то доступ до них був би наданий саме цій державі. Обидві сторони сподівалися на різний результат вирішення спору, але рішення Суду виявилося подвійним і встановлена лінія розмежування стала компромісом, що є обов'язковим для обох сторін. Припускається, що головною причиною такого рішення Міжнародного суду ООН стала відмова України від співробітництва з американським інвестором (Ванко) у розробці шельфу.

Ключові слова: розмежування у Чорному морі, міжнародне право, Міжнародний суд ООН, морські кордони, Румунія проти України.

\section{АННОТАЦИЯ}

Варикаша И. А. Дело о делимитации в Черном море (Румыния против Украины). Исследование позиций.-Статья.

В данной статье автором были изучены материалы о разграничении морских пространств, подготовленные с согласия соответствующих государств Международным судом ООН. Избрание тематики исследования обусловлено конкретной целью - показать то, каким образом Международный суд ООН интерпретировал договорные источники международного морского права, как он определил действующие обычные правовые нормы и принципы, а также применял международное право в делах о разграничении морских пространств сопредельных государств. Также было исследовано то, каким образом соответствующие факторы были учтены в конкретных спорах о делимитации морских пространств и изложены в качестве международно-правовых аргументов. Кроме того, изучение материалов рассмотрения дела позволило определить правовые позиции государств по проблемам разграничения морских пространств и изучить международно-правовую оценку таких позиций Международным судом ООН. Автор отмечает, что спор между Украиной и Румынией является территориальным спором по разграничению шельфа Черного моря. В случае, если Международный суд ООН признал бы о. Змеиный именно островом (как он обозначен на украинских картах), Украина должна была получить монополию на разработку нефти и газа на шельфе. Если бы этот участок земли был бы признан скалой, на чем настаивала Румыния, то доступ к ним был бы предоставлен именно этой стране. Обе стороны надеялись на разный результат разрешения спора, но решение Суда оказалось двояким и установленная линия разграничения стала компромиссом, являющимся обязательным для обеих сторон. Предполагается, что главной причиной такого решения Международного суда ООН стал отказ Украины от сотрудничества с американским инвестором (Ванко) в разработке шельфа.

Ключевые слова: разграничение в Черном море, международное право, Международный суд $\mathrm{OOH}$, морские границы, Румыния против Украины. 